\title{
Miljøterapeutiske utfordringer i møte med suicidale pasienter
}

\author{
Ved Heidi Hetland og Henning Herrestad
}

\section{Vi vil i denne artikkelen beskrive hva slags kompetanse og ferdigheter miljøterapeuter i en døgnavdeling bør ha for at de skal kunne bidra til at det skjer en terapeutisk prosess hos pasienter med selvmordsrisiko.}

\section{Innledning}

De nasjonale retningslinjene for forebygging av selvmord i psykisk helsevern pålegger helseforetakene ansvar for at alt personell innehar tilstrekkelig kompetanse til å utføre sine oppgaver (Sosial- og hel sedirektoratet, 2008). Det er særlig fokus på behandlingspersonal ets kompetanse. M iljøterapi er ikke omtalt ut over prosedyrene for observasjon av pasienter i forbindelse med selvmordsrisiko, der tiltakene kontinuerlig observasjon og intervallobservasjon beskrives. Vi ønsker å påpeke at en bedre helsetjeneste for pasienter med selvmordsproblematikk også forutsetter opplæring om de særlige utfordringer man står overfor som miljøterapeut i møte med pasienter med selvmordsrisiko.

\section{Om miljøterapi}

Begrepene miljøterapi og miljøarbeid brukes om hverandre og er nært beslektet. "Felles for begrepene mål rettet miljøarbeid og målrettet miljøterapi er den systematiske bruken av ressurser som ligger i mil¡øet, forskjellen ligger i hva som er målet med arbeidet" (Linde \& N ordlund, 2006, s. 22). M iljøterapi har behandling som hovedfokus, og miljøarbeid har til rettelegging som fokus. Miljøarbeid utføres $i$ hovedsak utenfor institusjon i pasientens hjem. Begrepet brukes mest om omsorgen for psykisk utviklingshemmede og assosi-

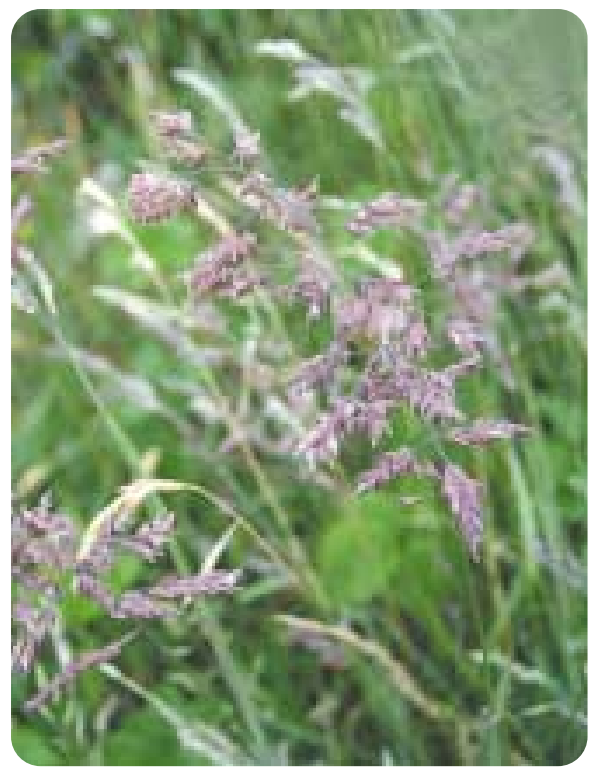

eres ofte med langvarige (livslange) behov. M iljøterapibegrepet er ofte knyttet til mer avgrensede behov i kortere perioder. Begrepet miljøterapi stammer fra idéene til $M$ axwell Jones om det terapeutiske samfunn. Behandlingsfokuset i begrepet er knyttet til institusjonsbehandling av psykiatriske pasienter (Linde \& N ordlund, 2006). Det ideol ogiske grunnlaget i tanken om det terapeutiske samfunn er at miljøet brukes aktivt i behandlingen av pasientene. Vi vil i denne artikkelen kun fokusere på begrepet miljøterapi.

I psykiatriske døgnavdelinger er det vanlig å skille mellom ansvar og oppgaver til behandlingspersonale og miljøterapeuter. Behandlere er først og fremst leger og psykologer. 0 gså annet personale som har fătt særskilt opplæring i å drive individuell behandling, blir noen ganger regnet som behandlere. M iljøterapeuter på en psykiatrisk døgnavdeling omfatter i hovedsak sykepleiere, hjel pepleiere og vernepleiere. Deres oppgave er observasjon og tilsyn av pasienten, iverksetting av behandlingstiltak, administrering av medisiner og administrering av praktiske gjøremål sammen med pasienten. A vdelingene bruker også i noen grad ufaglærte ekstravakter, men det er fagutdannet personale som har det faglige ansvaret for oppgaver som er blitt del egert til ekstravakter. M iljøterapi tar utgangspunkt i miljøterapeuters praktiske og konkrete handlinger i møte med pasienten. Den iverksettes etter observasjon av pasienten og reguleres $\mathrm{i}$ forhold til pasientens funksjonsnivå og pasientens tilbakemeldinger. Både det å ha kunnskaper om hva som er den beste handlingen og hvorfor noen handlinger er bedre enn andre, vil være viktig for å oppnå best mulig kvalitet på miljøarbeidet (Vatne, 2006).

\section{Balansepunktet i \\ miljøterapeutisk tilnærming}

Vatne (2006) beskriver hvordan miljøterapeuter når de bruker grensesetting som metode, lett kommer $i$ en vokterrolle ovenfor pasienten. Det kan ha sammenheng med at det er vanskelig å sette seg inn i pasientens situasjon når atferden er destruktiv eller selvdestruktiv. M iljøterapeuten kan være redd for selv å bli skadet, eller for at pasienten skal skade seg selv eller andre. Det er da lett å gå inn i en vokterrolle fordi man har behov for kontroll og ikke klarer å oppnå kontroll på andre måter enn ved bruk av tvang. I denne rollen har man ofte lite fokus på dialog, og opplever ofte frykt for å miste kontrollen. Da blir man lett rigid, og man oppnår i liten grad at pasienten selv korrigerer den uønskede atferden.

Vokterrollen kan sies à springe ut av et korrigerende perspektiv på hva miljøterapi innebærer. Et korrigeren de perspektiv har fokus på den ønskede endringen av atferden. U t fra et korrigerende perspektiv innebærer miljøterapeutens oppgaver å bidra til at pasienten får det miljøterapeuten forstår som en "normal virkelighetsforståel se" og å oppdra pasienten til å rette seg etter det som for miljøterapeuten er "normale normer for sosial atferd." En korrigerende miljøterapeutisk tilnærming bidrar i liten grad til positiv endring for pasientene og oppleves ofte som krenkende (Vatne, 2006; Borg \& Topor, 2003). $M$ ange utageringssituasjoner i en psykiatrisk avdeling starter med forsøk på korrigering og grensesetting som eskalerer slik at bruk av tvang blir nødvendig for at hjelperne skal gjenvinne kontroll over situasjonen.

Shneidman (1993) beskriver selvmordsatferd som en krisetilstand forårsaket av udekkede behov som fører til en sterk opplevel se av uutholdelig psykisk smerte. De udekkede behovene er knyttet til opplevelser av avvisning, mangel på aksept og forståelse, tap av kontroll, truet selvbilde, opplevd krenkelse, skam, nederlagffølelse og opplevel se av å være forlatt. $M$ ange pasienter med sel vmordsproblematikk er svært sårbare, og miljøterapi gitt ut fra et korrigerende perspektiv vil kunne påføre pasienten nye opplevelser av nettopp mangel på aksept og forståelse, tap av kontroll, krenkelse, skam og nederlag. Williams (2001) vektlegger i tillegg personens opplevelse av at krisetil standen vil vare evig, at det ikke er noen vei ut. En korrigerende tilnærming vil kunne 
forsterke denne opplevelsen av å være hjel peløs og fanget.

Korrigering av atferd er i mange tilfeller nødven dig. Miljøterapeutens fokus i situasjonen er av betyding for resultatet. Er det den ønskede endringen av atferden som er i fokus, eller er det pasientens opplevelse av situasjonen?

Vatne kontrasterer et slikt korrigerende perspektiv med miljøterapi gitt ut fra et anerkjennende perspektiv, som innebærer at miljøterapeuten viser aksept og respekt for pasientens egen forståelse av seg selv og sin situasjon. En søker gjennom en an erkjennende tilnærming å finne pasientens egen "forandringsmotor", det vil si at pasienten gjennom økt innsikt finner sin indre motivasjon for endring. I dette perspektivet er det viktigere at miljøterapeuten forstår pasientens virkelighetsforståelse enn at pasienten forstår miljøterapeutens virkelighetsforståelse. For å få tak i pasientens virkelighetsforståelse kan man stille pasienten spørsmål som "H va tenker du om dette?".

$\AA$ arbeide ut fra et anerkjennende miljøterapeutisk perspektiv krever at miljøterapeuten evner å gå inn i en empatisk prosess og setter seg inn i hvordan det er å være pasienten. D en empatiske kapasiteten utfordres i møte med destruktiv atferd, og man kan lett oppleve maktesløshet og tro at man ikke kan hjelpe. Dette fører ofte til at man trekker seg tilbake i kontakten, noe pasienten kan oppleve som en avvisning. En annen fare kan være at pasientens sterke psykiske smerte og håpløshet gjør miljøterapeuten overveldet slik at vedkommende ikke ser noe annet perspektiv enn pasientens. M iljøterapeuten kan da lett danne seg en fatalistisk oppfatning om at pasientens selvmordsatferd i liten grad lar seg endre i og med at den er villet av pasienten selv. Ut fra en slik oppfatning er det lite rom for annen miljøterapi enn beskyttelsestiltak som overvåkning og kontrolltiltak for å hindre eventuelle selvmordsforsøk mens pasienten er innlagt. For å bidra til refleksjon og endring av selvmordsatferd hos pasienten er det viktig at miljøterapeuten har kunnskap om selvmordsproblematikk, blant annet at selvmordstanker ikke er konstante i styrke og form (R etterstøl et.al., 2002). M ed riktige intervensjoner kan man bidra til at sel vmordsatferd avtar.
M an kan også motarbeide personaletsavmaktsfølel se ved at personalet på avdelingen sammen forsøker å finne felles mål for behandlingen av pasienten. Dette kan gjøres ved å stille spørsmål som: "H va kan vi hjelpe pasienten med? $\mathrm{H}$ va ønsker vi å få til i behandlingen av denne pasienten? $H$ va er hovedutfordringen? $H$ va er pasientens perspektiv på dette?"

I tillegg til å vise interesse for pasientens egen forståelse, innebærer et anerkjennende perspektiv å gi pasienten reell innflytelse på hvilke tiltak som iverksettes. Pasienten får være med både å velge og å eval uere tiltak. Dette bidrar til større autonomi og økt mestring hos pasienten (O ddli og Kjøs, 2001). Det er krevende for miljøterapeuten fordi det gir mindre kontroll og forutsigbarhet. $\AA$ arbeide ut fra et anerkjennende perspektiv krever derfor at miljøterapeuten har god kompetanse i å vurdere pasientens tilstand.

G underson beskriver fem miljøterapeutiske tilnærminger knyttet til pasientens funksjonsnivåer: beskyttelse, støtte, struktur, en gasjement og gyldiggjøring (Brathetland et al., 2004 ). G underson (1978) har bidratt til å konkretisere begrepet miljgterapi. Vi vil vise hvordan hver av disse tilnærmingene byr på spesielle utfordringer for miljøterapeuter når de står overfor pasienter med suicidal atferd.

\section{Beskyttelse}

Tilnærmingen beskyttelse har som mål å beskytte pasienten mot å skade seg selv eller andre. De nasjonale retningslinjene for forebygging av selvmord i psykisk helsevern krever at kontinuerlig observasjon benyttes ved høy selvmordsfare. Kontinuerlig observasjon omfatter total overvåking av pasienten. Kontinuerlig observasjon erstattes med intervallobservasjon etter definerte maksimumsintervaller når kontinuerlig observasjon ikke lenger er nødvendig. Denne overgangen i tilsyn sgrad skal være begrunnet i journal. Det skal også finnes prosedyrer for sikring mot fysiske farer som hengning og utsprang, bestemmelser om undersøkelse av rom og eiendeler, samt kroppsvisitasjon og beslag. A lle disse tiltakene har fokus på å kontrollere at pasienten ikke skader seg.

Det er behandleren, ikke miljøterapeuten, som er faglig ansvarlig for avgjørelsen

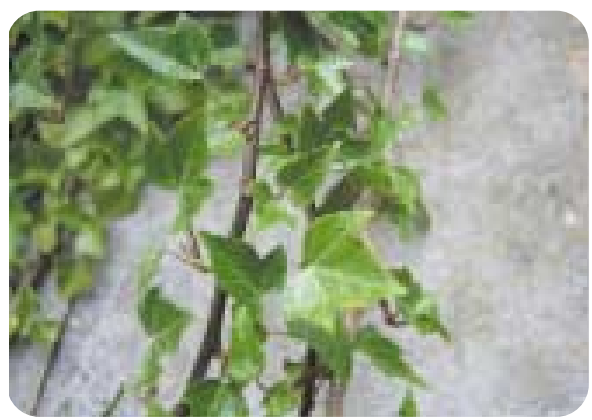

om hva som er nødven dige beskyttel sestiltak. M iljøterapeutens oppgave er i hovedsak å gjennomføre beskyttelsestiltakene. 0 fte vil miljøterapeuters observasjoner av pasienten utgjøre en del av behandlerens vurderingsgrunnlag. Tilsynsgrad bør derfor være tema for refleksjon i teamet som arbeider med pasienten. A lle i behandlerteamet bør ha fokus på om beskyttel sestiltakene er nødvendige ut fra pasientens behov for sikkerhet, eller om de har grunnlag i egen frykt og/eller andres behov for kontroll og redsel for å gjøre feil.

M iljøterapeutens utfordring er å gjennomføre beskyttel sestiltakene ut fra et anerkjennende perspektiv. Dette innebærer at miljøterapeuten holder fast på dialogen med pasienten og fortsetter å etterspørre pasientens egen forståelse av situasjonen. M iljøterapeuten må være tydelig i formidlingen av sine egne intensjoner, for eksempel: "Vi vil passe på deg fordi vi tror du kan komme til å skade deg selv. Du har gjort et alvorlig forsøk på å ta ditt eget liv, og vi vil gjøre det vi kan for å hindre deg i å gjøre et nytt forsøk. Jeg kan forstå at dette kan oppleves invaderende og krenkende. H va tenker du om dette?"

$\mathrm{N}$ år miljøterapeuten forvalter tiltaket beskyttelse, er det viktig å regulere kontakten i forhold til pasientens behov for avstand og nærhet. D et kan oppleves krenkende for pasienten å bli utsatt for kontinuerlig observasjon, og det kan være en belastning for pasienten å være så tett på et annet menneske over tid. Den tette kontakten kan også være kreven de for miljøterapeuter. M iljøterapeuten må kunne tematisere dette med pasienten og være direkte og konkret i kontakten. M iljøterapeuten kan åpne for samtale rundt dette ved å si: "V år oppgave er å redde liv. V i vil derfor følge deg opp gjennom kontinuerlig tilsyn. Du vil ikke være alene 
i noe tilfelle, ikke engang på toalettet. Jeg forstår at det kan oppleves krenken de å bli fulgt så tett. V i gjør dette for å forhindre at du tar ditt eget liv. $\mathrm{H}$ vis du vil kan vi snakke om hvordan dette oppleves."

A v og til er pasienter med suicidalatferd opphav til splitting i personalgruppen (Rovik, 2005). Splitting er en ubevisst prosess der en avsender (et individ eller en gruppe) projiserer egne uakseptable (benektede eller uerkjente) sider ved selvet over på andre, og hvor en mottaker stiller seg disponibel til å ta opp i seg og identifisere seg med disse egenskapene. Splitting i personalgruppen fører til at fokuset flyttes fra hva som er pasi entens behov til uenighet om hvem som har rett. I møtet med suicidale pasienter har miljøterapeuter en utfordring i å være på vakt overfor splitting og å være i dialog sammen om disse mekanismene.

$\mathrm{N}$ år pasienter utviser selvmordsatferd med impulser om å skade seg selv på livstruende måter, er beskyttel sestiltak nødven dige for å beskytte pasi enten. Samtidig er det en vanlig klinisk erfaring at et fokus på kontroll og tvangstiltak ikke fremmer det terapeutiske arbeidet med pasienten. Beskyttel sestiltakene er nødvendige for å hindre selvmord, men ikke tilstrekkelige til å få pasienten til å velge å ville leve. Ved å beskytte pasienten for mye vil pasientens eget initiativ bli undertrykket og bedringsprosessene kan forsinkes (Borg og Topor, 2003). Beskyttel sestiltak som kontinuerlig observasjon er ment å være kortvarige. Pasienten kan

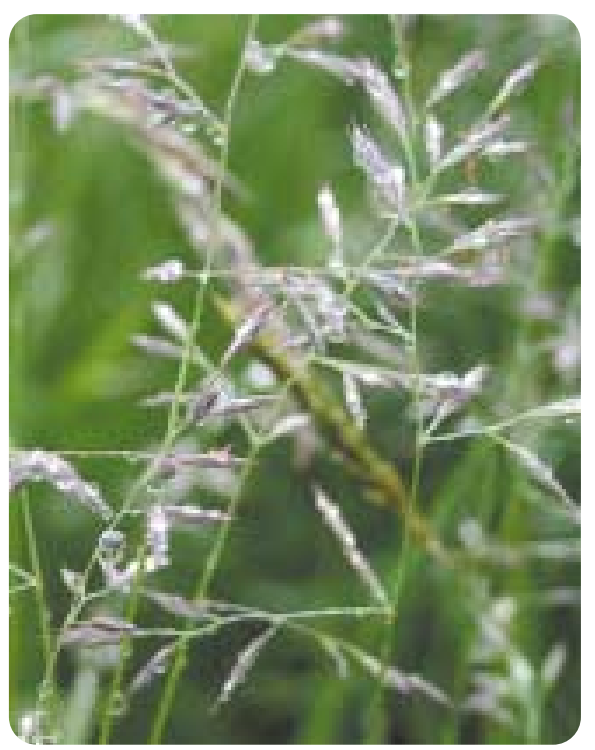

lett bli avhengig av at miljøterapeuter har kontroll, og få problemer med å ta tilbake kontrollen over selvmordsatferden. G od miljøterapi innebærer å balansere pasientens behov for beskyttel se mot pasientens behov for selv å ha kontroll og ta ansvar. Det er derfor en utfordring for miljøterapeuter å bidra til vurderingen av når tiltakene bør opphøre.

\section{Støtte}

$M$ ålet med tilnærmingen å gi støtte er å bidra til økt mestring hos pasienten. $\AA$ gi pasienten støtte omfatter særlig handlinger eller utsagn som fører til at pasienten opplever trygghet og styrket selvfølelse. Et eksempel kan være å oppmuntre til å delta på aktiviteter man vet pasienten mestrer. For å finne ut hvilke aktiviteter dette er, må man tematisere dette i dialogen med pasienten: " $\mathrm{H}$ ar du opplevd noe slikt som dette tidligere? Var det noe du opplevde som var til hjelp for deg den gangen? I hvilken grad tror du at det vil hjelpe om du gjorde dette nå også?"

Et spesi elt trekk ved selvmordsproblematikk er at pasienten ofte gir uttrykk for ambivalens, det vil si sterkt motstridende følelser i forhold til å ta sitt eget liv. Denne ambivalensen kan tematiseres i dialogen med pasienten. M iljøterapeuten spør først åpent om pasienten kjenner en slik ambivalens, og overlater til pasienten å beskrive dette. Da er det lettere for pasienten å se og akseptere at han faktisk er ambivalent. Deretter får pasienten støtte til selv å definere hvilke faktorer som beskytter pasienten mot selvmord: "K an du fortelle meg hva som har holdt deg fra å ta ditt eget liv fram til nå?" Dette kan bidra til at pasienten får øye på de redningsfaktorene som holder ham i live.

Det er en utfordring for miljøterapeuten at enkelte pasienter mistolker forsøk på å gi støtte til å gj ennomføre aktiviteter som krav fra miljøterapeuten om hva pasienten må gjøre. H vis miljøterapeuten ikke anerkjenner pasi entens opplevelse av egen utilstrekkelighet, kan støttetiltak oppfattes som forsøk på bagatellisering og gi en opplevelse av å ikke bli tatt på alvor. For mye støtte over for lang tid kan bidra til at pasienten ikke kan utføre aktiviteter uten personalets oppmuntring. 0 gså støtte er en tilnærming som må balanseres mot andre tilnærminger.

\section{Struktur}

$M$ ålet med struktur som tilnærming er å redusere pasientens opplevelse av kaos og øke pasi entens opplevelse av mestring. Struktur handler om tiltak som skaper forutsigbarh et i pasientens hverdag. Struktur skapes ofte ved å inngå avtaler med pasienten. Det kan være å lage og følge opp dagsplaner og ukeplaner sammen med pasienten, eller å gjennomføre planlagte aktiviteter og samtaler sammen med pasienten.

Pasienter med selvmordsproblematikk er ofte i en livssituasjon preget av kaos og problemer på flere områder. $\varnothing$ konomiske og administrative problemer kan oppleves som uoverkommelige for pasienten. Det kan være at pasienten ikke har åpnet post og betalt regninger på flere måneder. En måte å bidra til å redusere pasientens psykiske smerte på, er å hjelpe pasienten med å rydde opp i kaoset og å løse en del av de aktuelle problemene. $U \mathrm{t}$ fra et korrigerende perspektiv vil miljøterapeuten gjøre dette ved å forsøke å overtale eller overbevise pasi enten om hva som er nødvendige tiltak. Denne tilnærmingen gjør pasienten til mottaker og ikke til aktør. $\AA$ gi støtte og struktur ut fra et anerkjennende perspektiv innebærer at miljøterapeuten toner ned sin egen rolle og betydning som hjelper, og at man får pasienten til å beskrive hva pasienten opplever som stressfaktorer, til å rangere problemene og å avdekke sammenhenger: " $\mathrm{H}$ va tenker du selv om den situasjonen du er i? Kan vi sammen finne ut om noen av disse problemene er viktigere enn andre, og om noen av dem kan vente? E r det noe vi kan gjøre straks for å lette presset du opplever?"

\section{Engasjement}

$M$ ålet med engasjement som tilnærmingsmåte er å motvirke passivitet og å hjelpe pasienten til å etablere eller reetablere sosiale nettverk. D et handler om å få pasienten til å involvere seg i seg selv og andre. Dette kan gjøres ved for eksempel å rette fokus mot pasientens nettverk: "Jeg ser at du har en del besøk. D et kan se ut som om det er mange som bryr seg om deg. $\mathrm{H}$ ar du gjort deg noen tanker om dette?" Gjennom engasjement er det også et mål å øke pasientens opplevelse av ansvar og 


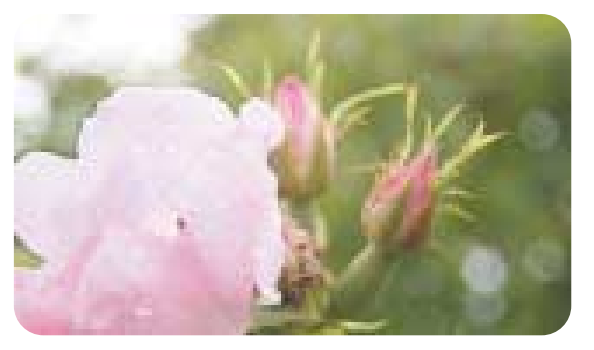

forståel se for seg selv og andre. G ruppeaktiviteter er viktige tiltak i denne sammenheng fordi de gir mulighet til samhandling med andre. Slike gruppeaktiviteter $i$ avdelingen fremmer en sosial trening som kan bidra til økt mestring også utenfor avdelingen. G ruppesamtalen kan dreie seg om hvordan det er å være innlagt på avdelingen. Pasientene gir ofte tilbakemelding om at gruppemøtene med andre pasienter er viktige for dem. De forteller om opplevelse av støtte og fellesskap.

I og med at tilknytning til andre er så viktig for at pasienter med selvmordsproblematikk skal orientere seg i en livsbevarende retning, er det lett for miljøterapeuten å overinvolvere seg. D et innebærer at miljøterapeuten blir overivrig i ønsket om å hjelpe, og presser pasienten til ting som er knyttet til miljøterapeutens ønske og behov for progresjon og bedring for pasienten. 0 gså i forhold til tilnærmingen engasjement må miljøterapeuten arbeide ut fra et anerkjennende perspektiv der man har et ambisjonsnivå som er til passet pasientens opplevelse av hva som er mulig og ønskelig å få til.

\section{Gyldiggjøring}

Gyldiggjøring innebærer handlinger og ytringer som bekrefter pasientens individualitet og egenart. Bekreftelse betyr her å gi kraft til pasientens egen opplevelse av verden. M iljøterapeuten bekrefter pasientens egenart, og viser at det er rom for å tolerere og akseptere annerledeshet. Dette kan tematiseres i samtale ved at man utfordrer pasienten med spørsmål som: "J eg forstår at du synes det er vanskelig å føle at du er annerledes enn andre, men gjør det noe om du ikke er som alle andre? K anskje du kan ha noe å tilføre siden du synes å ha et annet perspektiv?" M an gir også pasienten anledning til å gjøre feil for selv å lære gjennom egen erfaring.

"Prøv, så ser vi hvordan det går. H va tror du kan skje om det ikke blir slik du har tenkt deg?"

B ruk av gyldiggjøring som tilnærming forutsetter at pasienten er i en bedre fase av sykdomsforløpet. Er pasienten for eksempel psykotisk, har han redusert evne til å tolke ting som blir sagt og gjort, og forsøk på gyldiggjøring kan gjøre pasienten redd og fortvilet. Behovet for tiltak innen tilnærmingen gyldiggjøring må derfor bal anseres mot behovet for beskyttelse og støtte. V årt poeng har vært å vise at også disse tilnærmingene best kan gjennomføres ut fra et anerkjennende perspektiv.

\section{Avsluttende kommentarer}

I psykisk helsevern legges det økende vekt på behandlernes utdanning og kompetanse, og på deres ansvar og plikter. De nasjonale retningslinjene for forebygging av selvmord i psykisk helsevern er et uttrykk for dette. Det er miljøterapeuter som er sammen med pasienten 24 timer i døgnet. Vi vil påpeke at miljøterapeutisk virksomhet er en viktig faktor i det forebyggende arbeidet i forhold til pasienter med selvmordsrisiko.

Det er viktig å bidra til å redusere usikkerhet og avmaktsfølelse hos miljøterapeuter gjennom å gi opplæring i prinsippene for miljøterapeutisk tilnærming og kunnskap om suicidale prosesser.

Retningslinjene setter et helt nødvendig fokus på iverksettelsen av nødven dige beskyttelsestiltak overfor pasienter med selvmordsproblematikk. Samtidig innebærer slike beskyttelsestiltak at man tar kontroll fra pasienten. Vi snakker ofte om "å ha is i magen" når vi arbeider med suicidale pasienter. D et innebærer å tørre å overlate kontroll til pasienten. Det er derfor viktig kun å iverksette beskyttelsestiltak som skjerming eller kontinuerlig observasjon ut fra pasientens behov, og ikke med bakgrunn i personalets behov for kontroll eller redsel for å gjøre feil. Det er også viktig å gjennomføre slike beskyttelsestiltak ut fra et anerkjennende perspektiv der man fastholder dialogen med pasienten.

$\AA$ være en god miljøterapeut overfor pasienter med selvmordsproblematikk krever spesielle ferdigheter som å kunne være direkte og personlig utspørrende uten å være invaderende, å kunne være nøytral uten å være avvisende, og at man klarer å være empatisk uten å bli overveldet. Det kreves en modenhet og trygghet hos miljøterapeuten som kun kan vinnes gjennom kunnskap, erfaring, refleksjon og veiledning.

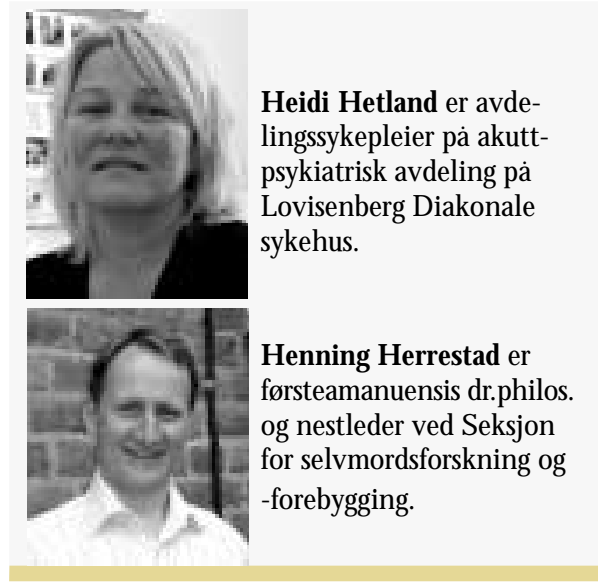

\section{Referanser}

Borg, M . \& Topor, A . (2003). Virksomme relasjoner. $0 \mathrm{~m}$ bedringsprosesser ved al vorlige psykiske lidelser. O sl o: Kommun eforlaget.

Brathetland, O., Dahle, A .S., Henriksen, A .T. H ammelvold, U .E., N ijkamp, S., Smedvik, K., Stokka, M., Torgrimsen, C., Tytlandsvik, M., Vevatne, K., $\varnothing$ stebø, G ., A anderaa, M .M., H aaland, $T \&$ Thorsen, G.R.B. (2004). Miljøterapi en modell for tenkning holdning og handling $i$ en psykiatrisk institusjon. Stavanger: Psykiatrisk opplysningsfond.

G underson J.G . (1978). D efining the therapeutic process in psychiatric milieus, Psychiatry, 41,327 335.

Linde, S. \& N ordl und, I. (2006). Innføring i profesjonelt miljøarbeid. Systematikk, kvalitet og dokumentasjon. O slo: U niversitetsforlaget

O ddli, H.W. \& Kjøs, P. (2001). U behaget ved makt. Focus, 29, 285-291.

Rovik, A .M . (2005). Selvskading og miljøterapi. Miljøterapeutiske utfordringer ved selvskadende atferd. N orsk tidsskift for sykepleieforskning, 7(2), 15-27.

Sosial og helsedirektoratet. (2008). N asjonale retningslinjer for selvmordsforebygging i psykisk helsevern. O slo: Sosial- og helsedirektoratet.

Retterstøl, N ., Ekeberg, Ø., \& M ehlum, L. (2002). Selvmord: Et personlig og samfunnsmessig problem. O slo: G yldendal akademisk.

Shneidman, Edwin S. (1993). Suicide as psychache: a clinical approach to self-destructive behaviour. N orthvale, N .J.: A ronson.

Thorgaard, L. (2006). E mpatiens bevarelse i relationsbehandlingen. Stavanger: $\mathrm{H}$ ertervig.

Thorgaard L. \& H aga E. (2006). G ode relationsbehandlere og god miljøterapi. Stavanger: $\mathrm{H}$ ertervig.

Vatne, S. (2006). Korrigere og anerkjenne. R elasjonens betydning i miljøterapi. 0 slo: Gyldendal.

W illiams, M . (2001). Suicide and attempted suicide: $U$ nderstanding the cry of pain. London: Penguin. 